\title{
ON-LINE LEARNING AND BURNOUT OF TEACHERS AND THE INTELLECTUAL HELPFULNESS OF STUDENTS
}

\author{
Aleksandra Jędryszek-Geisler \\ PhD, Warsaw Management University in Warsaw, Department of Psychology (Poland)
}

\begin{abstract}
Introduction: The coronavirus pandemic has made a huge difference in everyday life around the world. In the education sector, there was a need to rapidly adapt teaching methods and learning to the remote system. In a short time, teachers and students had to switch to online teaching and learning.

Research purpose: The purpose of the study is to identify (research questions):

1) Does teachers' well-being and experience in on-line teaching are related to professional burnout?

2) Does the well-being of students and their online learning experience correlate with intellectual helplessness?

3) Are there any differences between teachers and students in terms of well-being during distance learning?

4) Are there any differences in the intensity of teachers 'professional burnout and students' intellectual helplessness due to the duration of on-line learning?

Material and methods: 1000 people have been tested so far. By the time of the conference, the number of people surveyed is likely to increase. The variables will be measured using the Maslach Burnout Inventory and the scale of intellectual helplessness of Grzegorz Sędek and personal records.

Results: In order to obtain answers to the research questions, analysis of the correlation and differences between the studied groups will be carried out.
\end{abstract}

Keywords: Online teaching, online learning, burnout, intellectual helplessness.

\section{Introduction}

The coronavirus pandemic has made a huge difference in everyday life around the world. In the education sector, there was a need to rapidly adapt teaching methods and learning to the remote system. In a short time, teachers and students had to switch to online teaching and learning. Consequently, they had to face completely different challenges very quickly. Additionally (especially for teachers) it was a situation in which they had to deal with new technologies in a very short time and with high intensity. Students have been drastically isolated from their peers and still have to struggle with self-study to this day at home, without direct teacher support. Remote learning continues in many countries around the world with short breaks for over a year. In this situation, the author decided to conduct research among students and teachers, which has been ongoing since March 2020 and is still being continued.

\section{Research purpose}

The purpose of the study is to identify (research questions):

Does teachers' well-being and experience in on-line teaching are related to professional burnout? helplessness?

Does the well-being of students and their online learning experience correlate with intellectual learning?

Are there any differences between teachers and students in terms of well-being during distance

Are there any differences in the intensity of teachers 'professional burnout and students' intellectual helplessness due to the duration of on-line learning?

\section{Hypotheses}

1. Teachers 'well-being with online learning correlates with teachers' burnout.

2. The teachers' experience in online learning correlates with professional burnout. 
3. The well-being of students in relation to on-line learning correlates with intellectual helplessness.

4. The experience of students in online learning correlates with intellectual helplessness.

5. There are no differences in how students and teachers feel about online learning. learning

6. There are differences in the intensity of teacher burnout due to the duration of on-line

7. There are differences in the intensity of intellectual helplessness of students due to the duration of on-line learning.

\section{Material and methods}

The sample of respondents consisted of 1,329 people (736 students and 593 teachers). The average age in the group of teachers is 44.06 - the youngest respondent was 22 years old, the oldest was 70 years old. The average age in the group of students is 16.72 - the youngest respondent was 10 years old, the oldest was 21 years old.

Variables were measured using:

- Maslach Burnout Inventory MBI-ES, authors: Christina Maslach, Susan E. Jackson and Richard L. Schwab in the Polish adaptation of Tomasz Pasikowski (2000);

- Intellectual Helplessness Scale SBI, author Grzegorz Sędek (1995);

- Own records, which contain questions necessary to define the characteristics of the group in terms of sociodemographic and situational variables.

\section{Results}

1. Teachers' well-being with online learning is negatively correlated with exhaustion $(\mathrm{r}=-.37$; $\mathrm{p}<0.01)$ and depersonalization $(\mathrm{r}=-.24 ; \mathrm{p}<0.01)$, and positively with the sense of personal achievement $(\mathrm{r}=.30 ; \mathrm{p}<0.01)$.

2. The teachers' experience in online learning is not related to exhaustion $(r=-.97 ; p>0.05)$ and depersonalization $(\mathrm{r}=-.09 ; \mathrm{p}>0.05)$ and has a positive relationship with the sense of personal achievement $(\mathrm{r}=.21 ; \mathrm{p}<0.01)$.

3. The well-being of students in relation to on-line learning is negatively correlated with intellectual helplessness $(r=-.43 ; p<0.01)$. $\mathrm{p}>0.05)$.

4. The students' experience in on-line learning is not related to intellectual helplessness $(r=-.86$;

5. There are differences in the well-being of students and teachers in the online learning situation $(\mathrm{t}=-.97 ; \mathrm{p}<0.05)$.

6.There are significant differences in the severity of exhaustion $(\mathrm{t}=4.79 ; \mathrm{p}<0.01)$ and depersonalization $(\mathrm{t}=11.73 ; \mathrm{p}<0.01)$ due to the duration of on-line learning (in the second semester of $2019 / 2020$ they were significantly higher than in the first semester of 2020/2021), there are no differences due to the duration of online learning in terms of teachers' sense of personal achievement $(t=-0.79$; $\mathrm{p}<0.05)$.

7. There are differences in the intensity of intellectual helplessness of students due to the duration of on-line learning - the longer remote learning lasts, the greater the level of helplessness $(\mathrm{t}=-4.39 ; \mathrm{p}<0.01)$.

Conclusions: conditions.

1. It is essential to provide teachers with the necessary equipment, training and online work

2. Teachers have seen online learning as a challenge, have developed strongly in new technologies and the more experience they have in it, the greater their sense of personal achievement.

3. In order to prevent students 'intellectual helplessness, it is necessary to ensure their well-being in online learning (teachers' duty hours; individual consultations?).

4. Despite the much worse preparation of teachers to work with new technologies, they have adapted much better to the forced, new situation and cope with online learning now better (from the level of assessment of this situation) than students who, along with the longer learning time, line feel worse.

5. It is recommended to return to traditional education as soon as possible so that the intellectual helplessness of students does not increase.

Note: The above analyzes and recommendations apply primarily to primary school students and teachers. 


\section{References}

Maslach, C. (2009). Wypalenie - w perspektywie wielowymiarowej. W: H. Sęk (red.), Wypalenie zawodowe - przyczyny i zapobieganie (s. 13 - 32). Warszawa: PWN.

Maslach, C., Jackson, S. (1981). The measurement of experienced burnout. Journal of Occupational Behavior, 81(2), 99-113.

Maslach, C., Leiter, M.P. (2011). Prawda o wypaleniun zawodowym. Warszawa: PWN.

Maslach, C., Leiter, M.P. (2015). Pokonać wypalenie zawodowe. Sześć strategii poprawienia relacji z praca. Warszawa: Oficyna.

Maslach, C., Schaufeli, W.B., Leiter, M. (2001). Job bournout. Annual Review of Psychology, 52, 397-422.

Sędek, G. (1995). Bezradność intelektualna w szkole. Warszawa: Wydawnictwo Instytutu Psychologii PAN.

Sędek, G., McIntosh, D. N. (1998). Intellectual helplessness: Domain specificity, teaching style, and school achievement. [W:] M. Kofta, G. Weary, G. Sędek (red.), Personal control in action: Cognitive and motivational mechanisms (s. 391-418). New York: Plenum Press. 